Research Note

\title{
Use of Felled Junipers to Protect Streamside Willows From Browsing
}

\author{
Casey A. Matney, ${ }^{1}$ Chad S. Boyd, ${ }^{2}$ and Tamzen K. Stringham ${ }^{3}$ \\ Authors are ${ }^{1}$ Graduate Research Assistant, Department of Rangeland Ecology and Management, Oregon State University, \\ Corvallis, OR 97331; ${ }^{2}$ Rangeland Scientist, US Department of Agriculture-Agricultural Research Service, \\ Eastern Oregon Agricultural Research Center, 67826-A, Hwy 205, Burns, OR 97720; and ${ }^{3}$ Assistant Professor, \\ Department of Rangeland Ecology and Management, Oregon State University, Corvallis, OR 97331.
}

\begin{abstract}
Willow (Salix) communities are important components of riparian ecosystems. However, browsing by livestock and wildlife species can negatively impact willow size and abundance, and make restoration efforts difficult. A common solution has been fencing of affected willows to exclude ungulates, but fencing is expensive and may not complement desirable land management strategies. An alternative to fencing is the use of structures that limit access to streamside willows, without excluding ungulate access to the entire riparian zone. We examined the use of felled western juniper trees (Juniperus occidentalis Hook) placed over streamside willow shrubs. Four replicates of felled western juniper treatments (covered) and noncovered treatments were applied to a 1.2-km length of stream in southeastern Oregon. Willows $(<2 \mathrm{~m})$ within treatment areas were censused, tagged, examined for evidence of browse-use, and measured for maximum height during August 2002, before treatment. Posttreatment measurements were made in August and October 2003. Results indicate that by August 2003 (posttreatment) the average growth of willows in covered treatments was $25 \mathrm{~cm}(480 \%)$ greater than in noncovered treatments. By October 2003 (posttreatment), more shrubs were browsed in noncovered $(84 \%)$ than covered $(39 \%)$ treatments. Our data suggest that covering small willow shrubs $(<2 \mathrm{~m}$ tall $)$ with felled western juniper is an effective deterrent to browsing.
\end{abstract}

\section{Resumen}

Las comunidades de "Willow" (Salix) son componentes importantes de los ecosistemas ribereños. Sin embargo, el ramoneo del ganado y de especies de fauna silvestre puede impactar negativamente el tamaño y abundancia del "Willow" y dificultar las acciones de restauración de estos ecosistemas. Una solución común ha sido el cercar las plantas afectadas de "Willow" para excluirlas de los ungulados, pero el cercado es costoso y puede no complementar con estrategias deseables de manejo de la tierra. Una alternativa para cercar es el uso de estructuras que limitan el acceso a los "Willow" ubicados a un lado de la corriente, sin excluir el acceso de los ungulados al total de la zona ribereña. Examinamos el uso de árboles de "Western juniper" (Juniperus occidentalis Hook) cortados y colocados sobre los arbustos de "Willow" de un lado de la corriente. En una longitud de $1.2 \mathrm{~km}$ de una corriente de agua del sudeste de Oregon se aplicaron cuatro repeticiones de los tratamientos "Western juniper"cortado (cubierto) y sin cubrir. Los "Willows" $(<2 \mathrm{~m})$ presentes dentro del área experimental se censaron, etiquetaron y examinaron para ver evidencia de ramoneo y se midió la máxima altura en Agosto del 2002, antes de aplicarlos tratamientos. Las mediciones post-tratamiento fueron hechas en Agosto y Octubre del 2003. Los resultados indican que en Agosto del 2003 (posttratamiento) el crecimiento promedio de los "Willows" cubiertos fue de $25 \mathrm{~cm}(480 \%)$ mayor que el de las plantas sin cubiertas. Para Octubre del 2003 (post-tratamiento), más arbustos fueron ramoneados en el tratamiento de plantas sin cubrir (84\%) en comparación con el de plantas cubiertas (39\%). Nuestros datos sugieren que cubriendo arbustos pequeños de "Willow" $(<2 \mathrm{~m}$ de altura) con "Western juniper" cortado es una barrera limitante del ramoneo.

Key Words: cattle, deer, riparian management, Salix, herbivory, Oregon

\section{INTRODUCTION}

Willow (Salix) communities provide habitat for numerous wildlife species (Newsholme 1992; Larson and Larson 1996), aid in maintenance of stream channel structure and stability (Kovalchik and Elmore 1992), and provide shade for the

The Eastern Oregon Agricultural Research Center is jointly operated by the US Dept of Agriculture-Agricultural Research Service and the Oregon State University Agricultural Experiment Station.

Correspondence: Casey A. Matney, Dept of Rangeland Ecology and Management, Oregon State University, Corvallis, OR 97331. Email: matneyc@onid.orst.edu

Manuscript received 9 September 2004; manuscript accepted 6 August 2005. aquatic environment (Beschta 1997). However, browsing by livestock and wildlife species can cause declines in willow abundance (Kauffman et al. 1983; Kovalchik and Elmore 1992). Fencing can be used to exclude ungulates from the riparian zone (Peinetti et al. 2001), but rising costs of materials have made the construction of exclosures expensive. Also, exclosures limit access to livestock forage that would otherwise be available. An alternative to fencing may be the use of structures that limit access to streamside willows without excluding livestock and wildlife access to the entire riparian zone. Recently, interest among land managers has grown regarding the use of cut western juniper (Juniperus occidentalis Hook) as a structure to protect willows from browsing. Currently, there are more than 16.5 million ha of juniper 


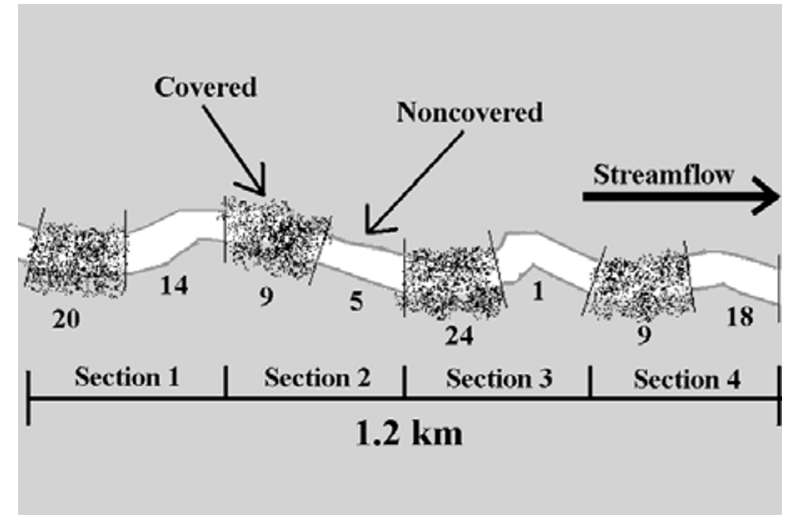

Figure 1. Study layout showing covered and noncovered treatments. The number of willow plants that were measured in each treatment is indicated below each treatment area.

woodland in the intermountain west, with nearly 900000 ha in eastern Oregon (Gedney et al. 1999). Juniper has increased 10fold in southeastern Oregon over the last century; this change is often associated with a reduction in diversity and production of native understory plant species in affected communities (Miller et al. 2000). Increases in abundance of juniper have made it readily obtainable in eastern Oregon. The objective of this study was to determine whether felled western juniper trees placed over small $(<2 \mathrm{~m}$ tall) willow shrubs could be used as an effective protective structure for reducing ungulate browsing. We hypothesized that incidence of browsing would decrease with willow covering and that willows covered with felled juniper would increase in height more than would noncovered willows.

\section{METHODS}

The study area was located at $2000 \mathrm{~m}$ elevation, $160 \mathrm{~km}$ east of Lakeview, Oregon. The study stream was a second-order Rosgen E6-type channel (Rosgen 1996), and the length of the study area was $1.2 \mathrm{~km}$. Willow species within the study area included Salix boothii Dorn, Salix lemmonii Bebb, Salix lutea Nutt., and Salix geyeriana Andersson. Most of the willows within the study area had an initial height less than $30 \mathrm{~cm}$, and many plants showed evidence of restricted growth (Keigley and Frisina 1998) due to browsing. During our study, cattle were not pastured within the study area. However, in June to late September 2002 and 2003, a few cattle were observed moving through the study area when they were being moved between adjacent pastures. Mule deer (Odocoileus hemionus hemionus) were often observed in the study area in summer and fall during both years of this study. Elk (Cervus elaphus nelsoni) were present in the vicinity but were not observed within the study area.

The study area was divided into 4 contiguous 304-m-long sections (4 replicates) with each section assigned 2 (152-m) treatments: 1) felled western juniper trees placed over the stream channel (covered) and 2) noncovered (Fig. 1). Both sides of the stream were included in the study. The upstream end of the study area was randomly selected for the starting position for layout of contiguous sections. At this end, within a distance of $20 \mathrm{~m}$, the specific starting point for section layout measure- ment was randomly selected. The covered treatment was randomly assigned to the first $152-\mathrm{m}$ segment within section 1. Treatments of noncovered and covered alternated thereafter proceeding downstream.

During spring 2002, western juniper trees $3-6 \mathrm{~m}$ in height were felled near the study area. Limbs were removed from one side of each tree bole, and limbed trees were transported to the study area in August. Most of the foliage had fallen from tree limbs during transportation. During the first week of September 2002, juniper treatments were applied with the flat side of each tree placed directly over the stream channel and streamside willow shrubs. Trees were placed across the channel in a perpendicular fashion, and no portion extended below the bankfull elevation. Mean percent aerial cover applied to covered treatments was approximately $40 \%$ in sections $1-3$ and $50 \%$ in section 4 (Fig. 1).

Willows within the study area were censused, tagged, and measured for maximum height during the first week of August 2002 (pretreatment). Latitude and longitude coordinates for each tagged willow were recorded by a handheld global positioning system (GPS). Evidence of browsing (browsed or not browsed) was noted for each shrub. Numbered aluminum tags and road survey tassels were used to identify individual willow plants. Tags and tassels were secured to $25-\mathrm{cm}-$ long hooked wire stakes driven to the soil surface at the base of each willow plant. Willow shoots having a unique aboveground base exceeding $10 \mathrm{~cm}$ in distance from their nearest neighbor were considered separate individuals. Willow measurements and browse data on plants measured in 2002 were repeated (posttreatment) in August and October 2003. Shrubs were relocated posttreatment by sight or by using a metal detector and a handheld GPS.

A total of 100 willow plants were included in the data set (Fig. 1). The number of willows browsed and the mean willow height for each replicate $(n=4)$ were used to calculate treatment means and standard errors. All willows occurring $>3.5 \mathrm{~m}$ from the stream water's edge and any $>2 \mathrm{~m}$ in height were not included in the analysis. Measurements were made on young willows $(<2 \mathrm{~m}$ in height) because this size-class represents a critical life history stage in the development of willows that can be easily affected by browsing (Keigley and Frisina 1998).

\section{RESULTS AND DISCUSSION}

The number of shrubs that showed evidence of browse-use was similar during August pretreatment and posttreatment. Between $5 \%$ and $10 \%$ of willows in noncovered and covered treatments were browsed by the first week of August pretreatment and posttreatment (Fig. 2). Reexamining plants during mid-October posttreatment revealed that noncovered willows were twice as likely to be browsed as covered willows. The mean percent ( \pm standard error $[\mathrm{SE}]$ ) of willow shrubs browsed in noncovered and covered treatments $(n=4)$ was $39 \pm 11$ and $84 \pm 5$, respectively. This difference in willow use between August and October 2003 could be explained by decreases in quality and palatability of herbaceous forage occurring over the course of the growing season (Roath and Krueger 1982; Kauffman et al. 1983). This explanation is 


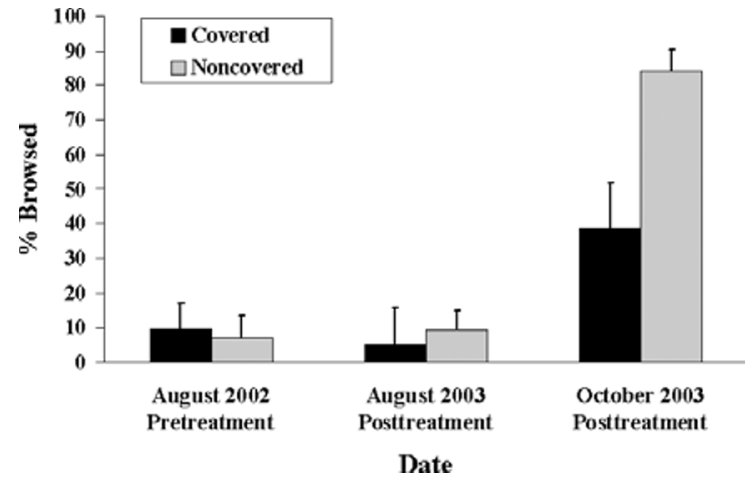

Figure 2. Mean percent of plants browsed for willows in covered and noncovered treatments for the time periods August 2002, August 2003, and October 2003. Vertical lines indicate standard error $(n=4)$.

consistent with our observation that grasses and sedges had senesced by mid-August, while willow foliage remained green through most of September.

In both covered and noncovered treatments willow height increased from August pretreatment to 1 August-year posttreatment. Covered treatments increased an average $( \pm \mathrm{SE})$ of $32 \pm 4 \mathrm{~cm}(69 \%)$ and noncovered treatments increased an average of $7 \pm 5 \mathrm{~cm}$ (16\%; Fig. 3$)$. Others have observed similar increases in willow growth following release from browsing. In Washington, Rickard and Cushing (1982) excluded livestock but not elk or deer from a 324-ha stream corridor with fencing. Before fencing, willows (Salix amygdaloides Andersson) in their study were sparse and discontinuous, and those that were present had been subject to chronic, intense herbivory. After 10 years of livestock exclusion, willows increased in stature and density, and formed a nearly continuous band along the stream. Similarly, in Oregon, Shaw (1992) documented a 40-cm increase in mean willow (Salix exigua Nutt.) seedling height when protected for 3 years inside cattle exclosures, while nonexcluded willows increased less than $5 \mathrm{~cm}$. However, even after being protected inside cattle exclosures for 4 years, browsing by deer was so great that mean height of excluded willows did not exceed $50 \mathrm{~cm}$. At the Starkey Experimental Forest in eastern Oregon, Case and Kauffman (1997) excluded deer and elk from willow communities. After 1 year, mean height growth was $10 \mathrm{~cm}$ for willows (Salix spp.) outside exclosures and $28 \mathrm{~cm}$ for those within. In year 2, growth was $1 \mathrm{~cm}$ for willows outside exclosures and $18 \mathrm{~cm}$ for those inside.

Average maximum willow height $( \pm \mathrm{SE})$ from August posttreatment to October posttreatment for covered and noncovered treatments increased $1 \pm 2 \mathrm{~cm}$ and $2 \pm 5 \mathrm{~cm}$, respectively. The average increase in height for noncovered treatments was strongly influenced by 1 of the replicates $(16$ $\mathrm{cm})$, and 3 of the 4 noncovered replicates actually decreased in height (average decrease for 3 replicates $=3 \pm 1 \mathrm{~cm}$ ) during this period. This suggests that noncovered willows were subjected to heavier browse-use from August to October than covered willows, even though the overall average maximum height for both treatments increased. Combined with our browse-use data, these findings support reports by others that browsing by herbivores increases during the late-season time period (Roath and Krueger 1982; Kauffman et al. 1983). Given

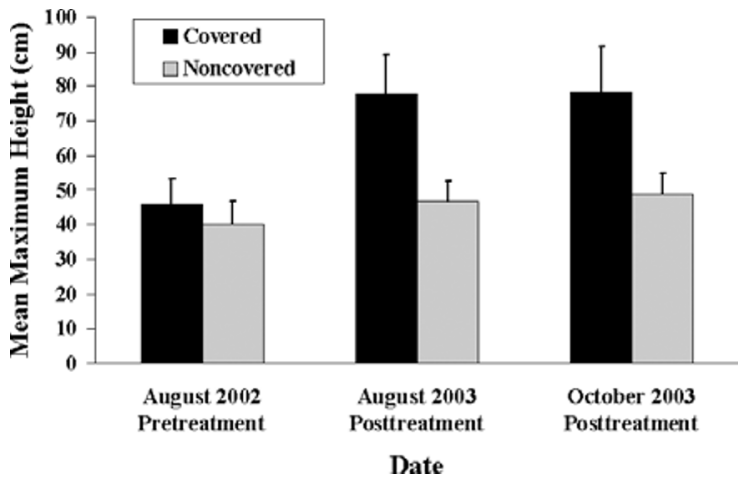

Figure 3. Mean maximum plant height for willows in covered and noncovered treatments for the time periods August 2002, August 2003, and October 2003. Vertical lines indicate standard error $(n=4)$.

that noncovered shrubs were twice as likely to be browsed from August to mid-October 2003, it is probable that ungulates browsed noncovered willows more often than covered willows throughout the previous fall and winter of 2002, which would account for treatment differences in willow growth between years. Willows were not remeasured during October 2002 or immediately before willow growth in spring 2003; these data would have helped to explain the differences in willow growth observed before the August posttreatment period, without having to infer from results obtained in October 2003.

The above results suggest a short-term decrease in willow browse-use following the addition of felled juniper cover. Longterm use of juniper cover may allow small willows to become tall enough to withstand exposure to browsing. Keigley and Frisina (1998) noted that willows become less susceptible to the negative affects of browsing as plants approach or exceed $2 \mathrm{~m}$ in height. This may be of importance to our study given that the cover of felled junipers will decline over time due to the natural process of decay.

\section{MANAGEMENT IMPLICATIONS}

In summary, our results indicate that felled juniper cover is effective in reducing ungulate browsing of small stature $(<2 \mathrm{~m}$ tall) willow shrubs. From September 2002 to August 2003, its use as a protective structure facilitated a $25-\mathrm{cm}(480 \%)$ greater increase in willow height than noncovered treatments. Browse rates were similar between treatments during August pretreatment and 1 August-year posttreatment. However, by 1 October-year posttreatment, willow shrubs in noncovered treatments were more than twice as likely to be browsed as those in covered treatments. In addition to providing an effective deterrent to browsing, the felling of junipers located adjacent to the stream may reduce juniper encroachment into the riparian zone. In these instances, the cost of using felled juniper could be less expensive than fencing large sections of stream. Further, using felled juniper may be more desirable than fencing in some cases given that the juniper treatment is not likely to exclude ungulate access to the entire riparian zone. Although our findings support the use of felled juniper as an effective alternative to fencing for protecting willows, further research is needed to determine whether excluding ungulates from willows with felled juniper cover increases incidence of 
browsing on adjacent uncovered willows. Additionally, the minimum amount of cover needed to effectively protect willow shrubs should be investigated. Finally, because mule deer were the only ungulates observed browsing willows during this study, it is unknown whether felled juniper treatments would deter all species of ungulates equally (e.g., cattle and elk). Data collection on this project will continue in an effort to determine the long-term implications of our treatments to the restoration of streamside willow communities.

\section{LITERATURE CITED}

BESCHTA, R. L. 1997. Riparian shade and stream temperature: an alternative perspective. Rangelands 19:25-28.

CASE, R. L., AND J. B. Kauffman. 1997. Wild ungulate influences on the recovery of willows, black cottonwood, and thin-leaf alder following cessation of cattle grazing in northeast Oregon. Northwest Science 71:115-126.

Gedney, D. R., D. L. Azuma, C. L. Bolsinger, and N. McKay. 1999. Western juniper in eastern Oregon. USDA Forest Service General Technical Report PNW-GTR464. Portland, OR: USDA Forest Service. $53 p$.

Kauffman, J. B., W. C. Krueger, and M. Vavra. 1983. Effects of late season cattle grazing on riparian plant communities. Journal of Range Management 36:685-691.

Keigley, R. B., and M. R. Frisina. 1998. Browse evaluation by analysis of growth Form-Volume I: Methods for evaluating condition and trend. Helena, MT: Montana Fish, Wildlife, and Parks. 153 p.
KovalchiK, B. L., and W. Elmore. 1992. Effects of cattle grazing systems on willowdominated plant associations in central Oregon. In: W. P. Clary, D. E. McArthur, D. Dedunah, and C. L. Wambolt [EDS.]. 1991. Proceedings of a Symposium on Ecology and Management of Riparian Shrub Communities. General Technical Report, INT-289. Ogden, UT: US Department of Agriculture, Forest Service. $232 \mathrm{p}$.

LARSON, L. L., AND S. L. LARSON. 1996. Riparian shade and stream temperature: a perspective. Rangelands 18:149-152.

Miller, R. F., T. J. Svejcar, and J. A. Rose. 2000. Impacts of western juniper on plant community composition and structure. Journal of Range Management 53:574-585.

Newsholme, C. 1992. Willows the genus Salix. Portland, OR: Timber Press. $224 \mathrm{p}$.

Peinetti, H. R., R. S. C. Menezes, and M. B. Coughenour 2001. Changes induced by elk browsing in the aboveground biomass production and distribution of willow (Salix monticola Bebb): their relationships with plant water, carbon, and nitrogen dynamics. Oecologia 127:334-342.

Rickard, W. H., And C. E. Cushing. 1982. Recovery of streamside woody vegetation after exclusion of livestock grazing. Journal of Range Management 35:360-361.

Roath, L. R., and W. C. Krueger. 1982. Cattle grazing influence on a mountain riparian zone. Journal of Range Management 35:100-103.

Rosgen, D. L. 1996. Applied River Morphology. Pagosa Springs, CO: Wildland Hydrology. $390 \mathrm{p}$.

Shaw, N. L. 1992. Recruitment and growth of Pacific willow and sandbar willow seedlings in response to season and intensity of cattle grazing. In: W. P. Clary, D. E. McArthur, D. Dedunah, and C. L. Wambolt [EDS.]. 1991. Proceedings of a Symposium on Ecology and Management of Riparian Shrub Communities. General Technical Report, INT-289. Ogden, UT: US Department of Agriculture, Forest Service. $232 \mathrm{p}$. 